\title{
Efektivitas Pengelolaan Kearsipan di Kantor Badan Kepegawaian Negara Regional IV Makassar
}

\section{The Effectiveness of Archival Management at the Office of the Regional IV State Civil Service Agency Makassar}

\author{
Irwanti $^{1}$, M. Nippi Tambe ${ }^{2}$, Jamaluddin ${ }^{3}$ \\ ${ }^{1,2,3}$ Universitas Negeri Makassar
}

\begin{abstract}
ABSTRAK
Dalam sebuah organisasi arsip digunakan untuk membantu dalam penyediaan informasi. Penelitian ini bertujuan untuk mengetahui pengelolaan kearsipan. Penelitian ini merupakan penelitian deskriptif kuantitatif. Populasi penelitian ini sebanyak 104 pegawai dengan mengambil sampel sebanyak 41 orang. Teknik pengumpulan data yang digunakan adalah observasi, angket/kuesioner, wawancara dan dokumentasi. Analisis data yang digunakan adalah analisis deskriptif. Hasil penelitian menunjukkan bahwa berdasarkan indikator pencatatan dan pendistribusian arsip termasuk dalam kategori efektif, indikator penyimpanan arsip termasuk dalam kategori efektif, indikator pemeliharaan arsip termasuk dalam kategori sangat efektif, dan indikator penyusutan arsip termasuk dalam kategori sangat efektif. Dengan demikian efektivitas pengelolaan kearsipan di Kantor Badan Kepegawaian Negara Regional IV Makassar termasuk dalam kategori sangat efektif
\end{abstract}

Kata kunci: Efektivitas, kearsipan, BKN

\section{ABSTRACT}

In an archive organization is used to assist in the provision of information. This study aims to determine the management of archives. This research is quantitative descriptive. The population of this study was 104 employees taking a sample of 41 people. Data collection techniques used were observation, questionnaire / questionnaire, interview and documentation. Analysis of the data used is descriptive analysis. The results of the study show that based on indicators of recording and distribution of archives included in the effective category, indicators of archive storage are included in the effective category, indicators of archive maintenance are included in the very effective category, and indicators of depreciation of records are included in the very effective category. Thus the effectiveness of filing management at the Office of the Regional IV Civil Service Agency Makassar is included in the very effective category

Keywords: Effectiveness, filing system, BKN

\section{PENDAHULUAN}

Dalam sebuah organisasi arsip digunakan untuk membantu dalam penyediaan informasi. Tujuan kearsipan itu sendiri adalah menyediakan data dan informasi secepatcepatnya dan setepat-tepatnya kepada yang memerlukan. Kearsipan mempunyai peranan sebagai pusat ingatan, sumber informasi serta alat pengawasan yang sangat diperlukan sebagai pendukung organisasi dalam rangka melaksanakan segala kegiatankegiatan, baik pada kantor-kantor, lembaga negara, swasta, dan perguruan tinggi (Peterson, 2007; Ricciardi, 2012; Schwartz \& Cook, 2002). Melalui arsip, masa lalu 
dikendalikan. Cerita-cerita tertentu diistimewakan dan yang lainnya terpinggirkan (Schwartz \& Cook, 2002). Dalam proses penyajian informasi agar pimpinan dapat membuat keputusan dan merencanakan kebijakan. Kearsipan menyangkut pekerjaan yang berhubungan dengan penyimpanan warkat atau surat-surat dan dokumen-dokumen kantor lainnya. Kegiatan yang berhubungan dengan penyimpanan warkat, surat-surat, dan dokumen-dokumen inilah yang selanjutnya disebut kearsipan. Kesadaran mengenai pentingnya arsip diketahui seluruh pihak dalam organisasi baik dari atasan hingga bawahan. Apa yang akan terjadi apabila dalam suatu organisasi tidak ada perhatian pada masalah arsip. Jika arsip dibiarkan maka akan menimbulkan permasalahan baru yaitu akan dikemanakan arsip tersebut dan tentunya akan kesulitan dalam pencarian suatu dokumen yang diperlukan, yang lebih berbahaya apabila surat atau dokumen tersebut hilang atau jatuh ke tangan orang yang tidak bertanggungjawab. Sistem pengelolaan kearsipan yang tepat mulai dari pencatatan sampai dengan pemusnahan adalah salah satu indikator penyelenggaraan pemerintahan yang baik, antara lain terlaksananya administrasi pemerintahan yang benar dan hal ini tidak terlepas dari terlaksananya penataan sistem pengelolaan kearsipan yang tepat sehingga dapat menciptakan efektivitas, efisiensi dan produktifitas bagi satu organisasi di lingkungan Pemerintah Kota Makassar. Efektivitas pengelolaan kearsipan pada suatu kantor kemungkinan dipengaruhi pula oleh pegawai yang bekerja pada unit kearsipan, sarana atau fasilitas yang dipergunakan dalam membantu pengelolaan arsip dan dana yang tersedia untuk pemeliharaan arsip tersebut. Sampai saat ini tampaknya masalah kearsipan kurang mendapat perhatian yang semestinya oleh berbagai instansi (baik pemerintah maupun swasta). Hal ini dapat kita jumpai dalam kehidupan sehari-hari, banyak kertas atau berkas arsip yang dipergunakan oleh para pedagang (di pasar-pasar, warung-warung) sebagai pembungkus. Padahal dilihat dari segi waktu/tanggal pengeluarannya, berkas tersebut masih tergolong berkas yang masih baru.

\section{METODE}

Penelitian ini menggunakan penelitian deskriptif kuantitatif. Populasi penelitian ini adalah seluruh pegawai di kantor Badan Kepegawaian Negara Regional IV Makassar yang berjumlah 104 orang, dan yang menjadi sampel penelitian adalah sebesar $40 \%$, atau sebanyak 41 orang. Teknik pengumpulan data yang digunakan adalah observasi, angket, wawancara dan dokumentasi. Teknik analisis data yang digunakan adalah persentase.

\section{HASIL PENELITIAN DAN PEMBAHASAN}

Data yang disajikan dan diolah adalah tentang Efektivitas Pengelolaan Kearsipan di Kantor Badan Kepegawaian Negara Regional IV Makassar. Untuk memperoleh gambaran mengenai pengelolaan kearsipan tersebut, yang diperoleh melalui instrumen 
penelitian dengan teknik angket dalam pengumpulan data. Penyajian dan pengolahan data diuraikan secara sistematis dengan menggunakan diagram.

\section{Pencatatan dan Pendistribusian Arsip}

Pencatatan dan pendistribusian arsip adalah surat yang diterima akan dicatat oleh petugas kearsipan pada suatu kantor baik menggunakan sistem buku agenda maupun kartu kendali kemudian menggolongkan arsip surat yang memiliki kode klasifikasi atau pokok masalah yang sama dan selanjutnya diurutkan sesuai dengan tanggal pencatatan surat kemudian didistribusikan kepada pihak yang bersangkutan. Untuk mengetahui hasil penelitian, dapat dilihat pada Diagram 1.

\section{Diagram 1.}

\section{Gambaran Pencatatan dan Pendistribusian Arsip}

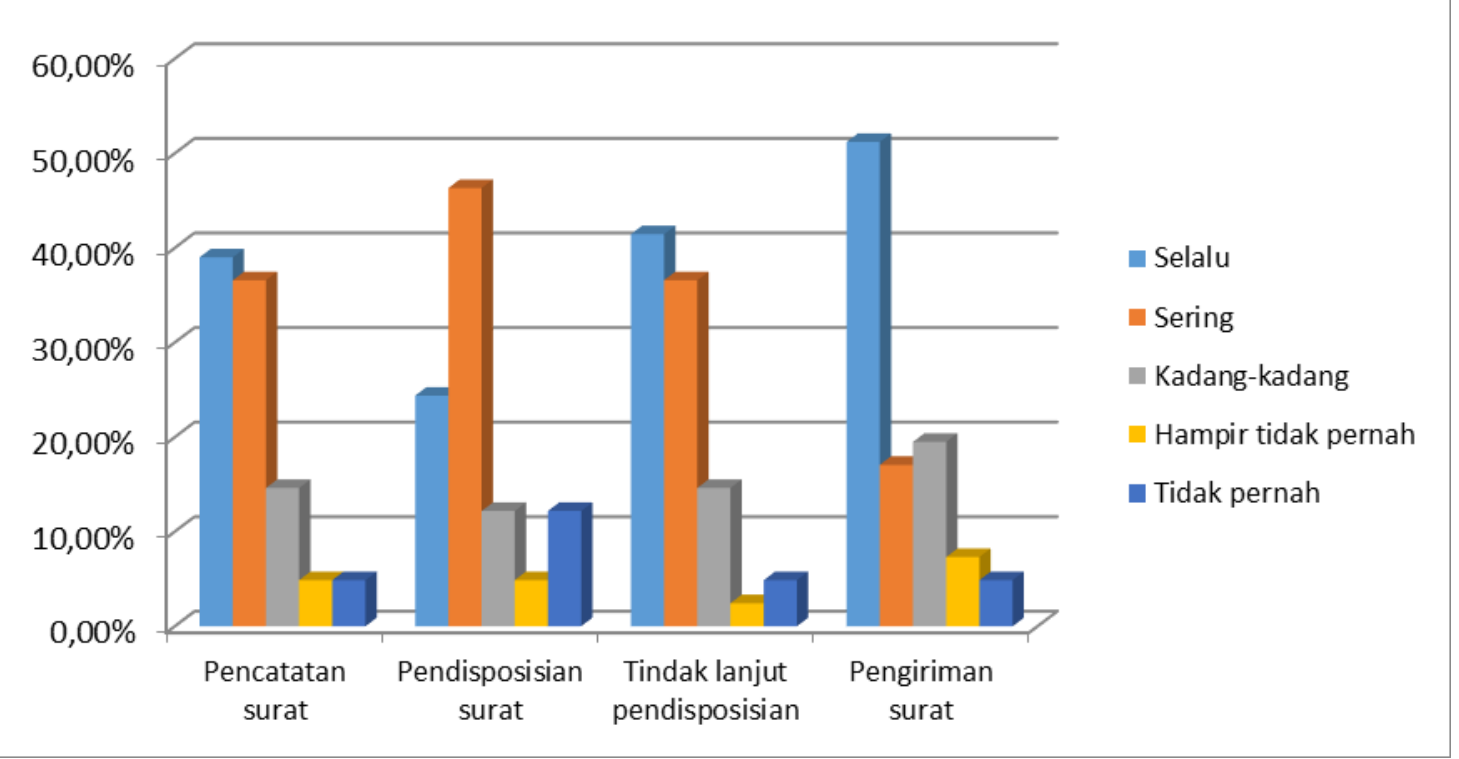

Sumber: Hasil olah data

Berdasarkan hasil olah data 39,02\% responden berpendapat bahwa pencatatan surat selalu dilakukan dan diolah sesuai dengan prosedur penerimaan surat masuk daripada terjadi penumpukan di atas meja kerja, berdasarkan hasil pengamatan, apabila ada surat masuk biasanya disimpan dulu, tidak langsung dikelola oleh petugas dikarenakan pegawai sibuk dengan pekerjaannya masing-masing dan biasanya surat masuk yang ditunda beberapa jam karena ada hal yang mendesak, dan masih ada surat sebelumnya, sehingga surat tersebut tertunda lagi untuk dikelola. Untuk pendisposisian surat sering dilakukan berdasaarkan tanggapan dari46,34\% responden, dari hasil pengamatan menunjukkan bahwa pimpinan di setiap unit kerja sebagian besar melakukan pendisposisian surat setelah ada surat masuk yang telah dicatat. Adapun jawaban responden yang 
menyatakan di unit kerjanya tidak dilakukan pendisposisian surat karena pimpinan sedang keluar melakukan atau adanya kesibukan lain sehingga surat yang masuk tidak didisposisi. Untuk tindak lanjut pendisposisian surat $41,46 \%$ responden berpendapat bahwa selalu ditindaklanjuti, sedangkan untuk pengiriman surat $51,22 \%$ responden berendapat bahwa surat selalu langsung dikirim. Berdasarkan hasil pengamatan kebanyakan surat keluar yang selesai diproses akan langsung dikirim ke alamat yang dituju, dan adapun surat tersebut proses pengirimannya ditunda beberapa jam sampai ada surat yang ditunda 1 hari kerja atau lebih hal tersebut dikarenakan pimpinan diruangan tidak ada sementara pengiriman surat tersebut sebelumnya akan ditanda tangani oleh pimpinan atau dapat persetujuan oleh pimpinan sebelum dikirim ke alamat yang dituju, karena tanpa persetujuan oleh pimpinan surat tersebut tidak akan dikirim. Jadi, surat tersebut harus ada persetujuan dari pimpinan

\section{Penyimpanan Arsip}

Penyimpanan arsip adalah dilakukan untuk keperluan penggunaan informasi yang terkandung di dalam surat saat kemudian hari diperlukan. Penyimpanan arsip surat juga erat kaitannya dengan tempat penyimpanan atau sistem penyimpanan arsip, lingkungan penyimpanan dimana arsip tersebut disimpan dan fasilitas kearsipan yang ada di kantor, sehingga pencarian arsip mudah ditemukan sewaktu-waktu diperlukan. Untuk mengetahui hasil penelitian, dapat dilihat pada Diagram 2.

\section{Diagram 2.}

\section{Gambaran Penyimpaan Arsip}

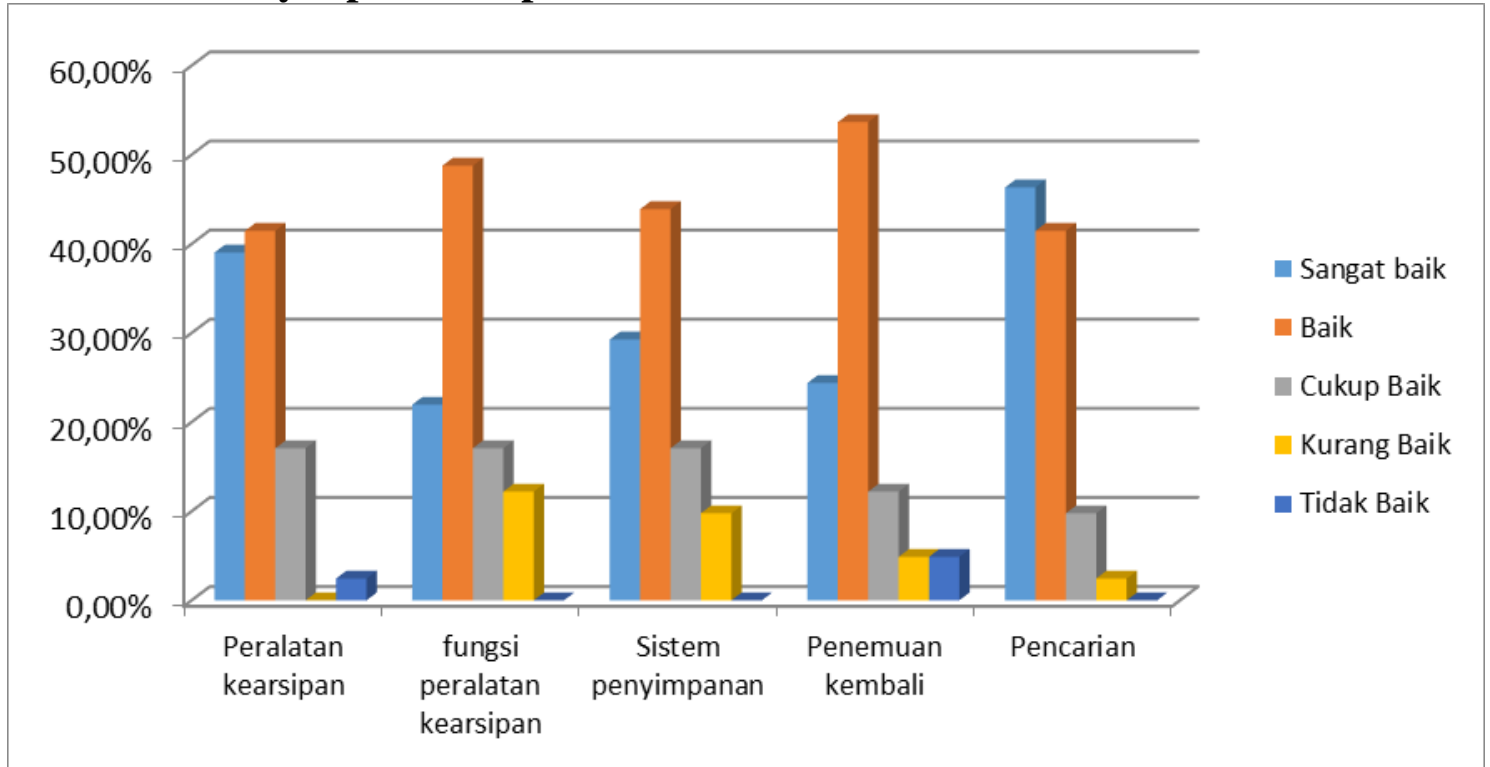

Sumber: Hasil olah data 
Berdasarkan hasil olah 41,46\% responden berpendapat bahwa peralatan kearsipan sudah memadai ini ditandai dengan banyaknya lemari tempat penyimpanan arsip. Dengan adanya tempat penyimpanan arsip di kantor arsip-arsip yang bertumpuk akan tersimpan di lemari peyimpanan. $48,78 \%$ responden berpendapat bahwa arsip dilindungi dengan baik peralatan dan perlengkapan yang digunakan dapat melindungi arsip dari kerusakan. 43,90\% sistem penyimpanan yang digunakan mempermudah penyimpanan arsip, 53,66\% responden berpendapat bahwa penemuan kembali arsip mudah ditemukan Penataan arsip secara baik, hanya bisa terlaksana apabila didukung oleh cara penyimpanan dengan baik seperti pengindeksan yang tepat, pemberian kode, menyortir surat. Oleh sebab itu penyimpanan arsip yang baik sangatlah membantu proses pengelolaan arsip yang efektif dalam kantor. Sedangkan pencarian kembali arsip kurang dari 1 menit menurut 46,34\% responden.

\section{Pemeliharaan Arsip}

Pemeliharaan arsip adalah kegiatan dengan melakukan pemeliharaan arsip dengan baik dan melakukan pencegahan kerusakan fisik arsip. Untuk mengetahui hasil penelitian, dapat dilihat pada Diagram 3.

\section{Diagram 3.}

\section{Gambaran Pemeliharaan Arsip}

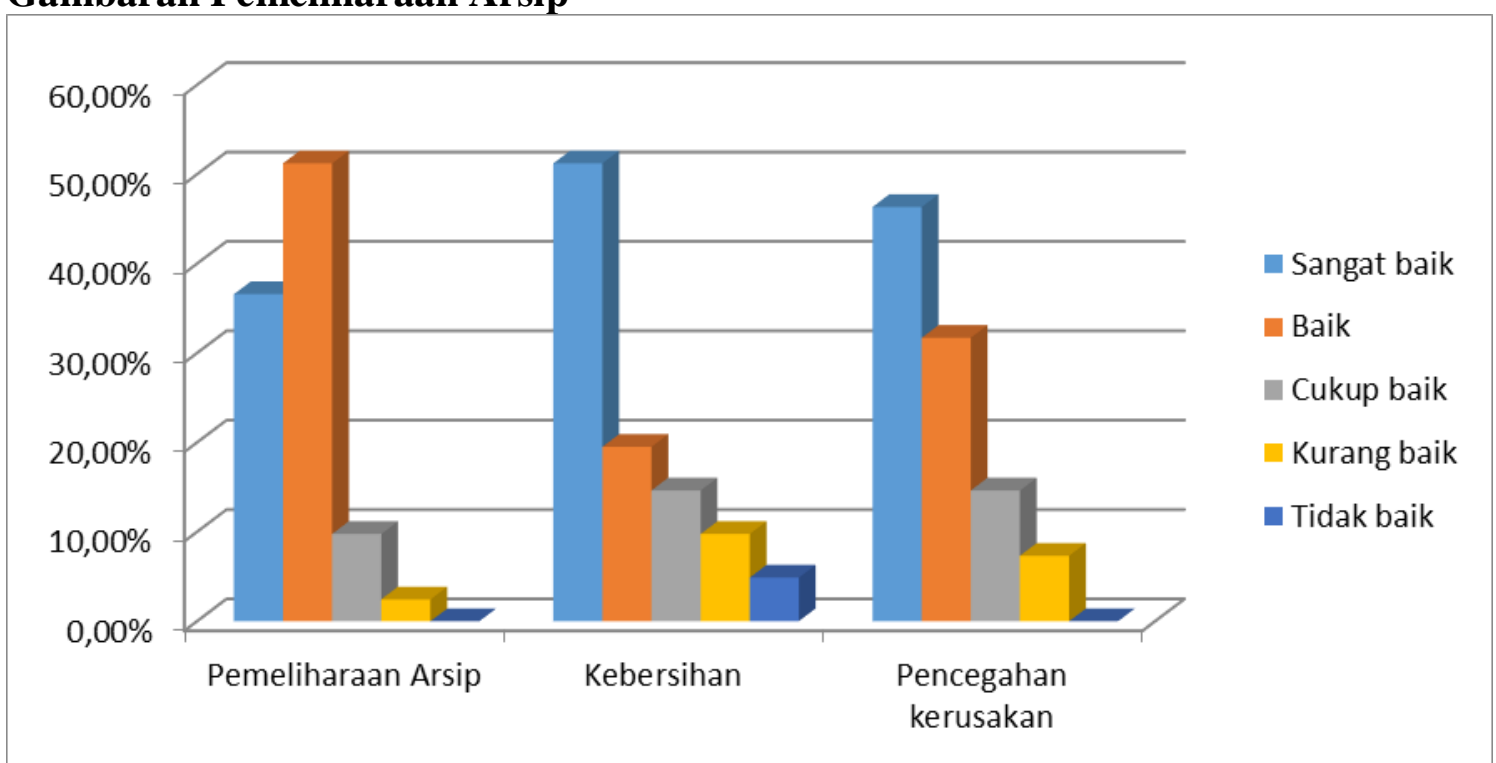

Sumber: Hasil olah data

Berdasarkan hasil penelitian, menurut $51,22 \%$ responden, arsip dipelihara dengan baik, Pemeliharaan arsip dilakukan agar arsip yang tersimpan tetap terjaga kondisi 
fisiknya dari faktor-faktor perusaknya. Ada tiga faktor yang dapat merusak arsip yaitu faktor fisik, faktor biologis dan faktor manusia. Arsip memiliki fungsi yang penting sebagai sumber informasi, sehingga perlu dipelihara dengan menjaga kondisi fisik arsip dari debu, jamur, air, kotoran, dan faktor perusak arsip lainnya. Kebersihan ruangan dalam pemeliharaan arsip menurut 51,22\% responden sangat diperhatikan dengan baik karena ruangan yang digunakan dalam menyimpan arsip sudah terjaga dari kebersihan sehingga arsip yang disimpan dapat terpelihara dengan baik. Adanya jawaban responden yang menyatakan kebersihan ruangan dalam pemeliharaan arsip kurang diperhatikan karena ada dalam unit kerja yang ruangannya dipenuhi dengan arsip-arsip yang belum tersimpan di lemari tempat penyimpanan arsip. Sementara pencegahan kerusakan selalu dilakukan. Pemeliharaan arsip sangatlah penting bagi arsip-arsip yang tersimpan ditempat penyimpanan arsip dan sangat dibutuhkan dalam menjaga keaslian arsip. Hal ini dikarenakan sering terjadinya kerusakan pada arsip yang kurangnya perawatan pada arsip itu sendiri. Oleh karena itu arsip-arsip harus tetap diperhatikan terutama dari pemeliharaannya sehingga dapat mencegah kerusakan arsip tersebut.

\section{Penyusutan Arsip}

Penyusutan arsip adalah kegiatan yang dilakukan dengan mengurangi jumlah arsip surat dari tempat penyimpanan. Melakukan pemusnahan arsip yang dinilai sudah habis masa berlakunya dengan menghancurkan kondisi fisik dari arsip tersebut. Kegiatan penyusutan arsip ini meliputi penilaian/pemindahan, pemusnahan dan penyerahan. Untuk mengetahui hasil penelitian, dapat dilihat pada Diagram 4.

\section{Diagram 4.}

\section{Gambaran Penyusutan Arsip}

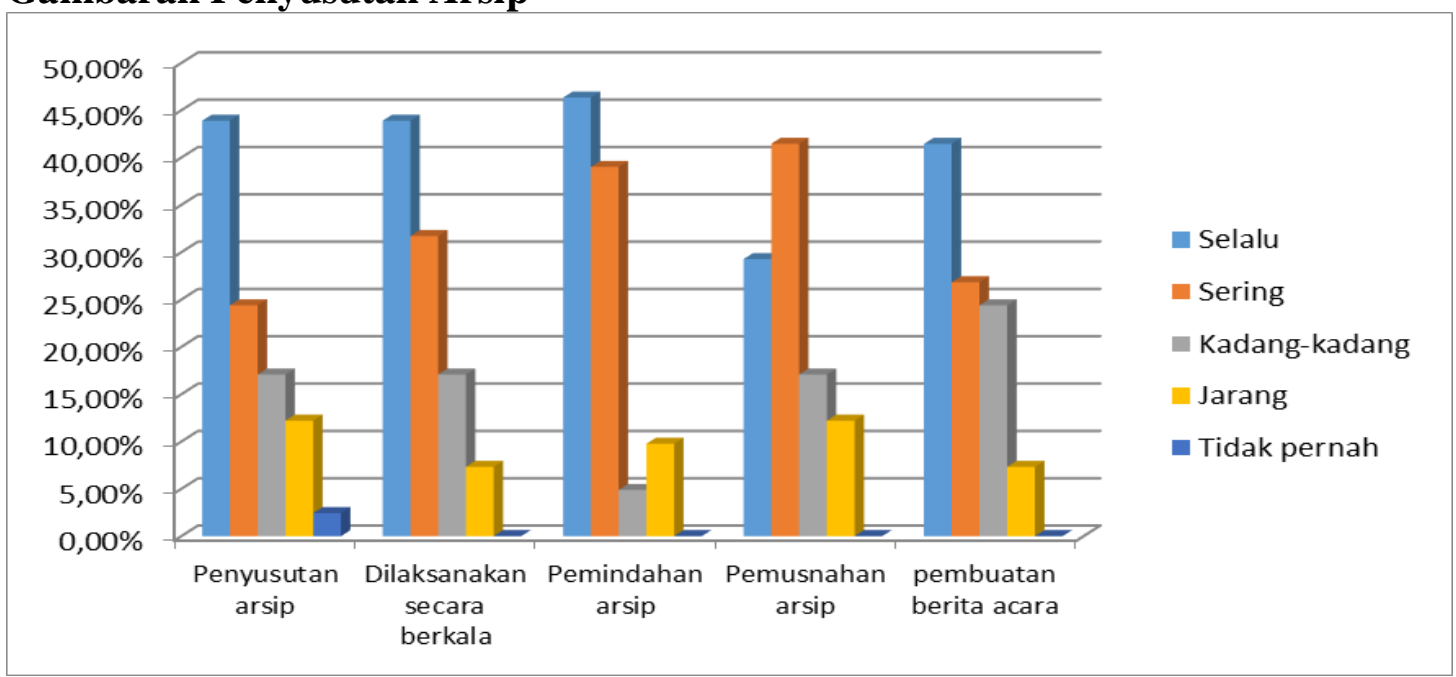

Sumber: Hasil olah data 
Berdasarkanhasil penelitian, menurut $43,90 \%$ repsonden penyusutan arsip sering dilakukan dan dilakukan secara berkala, pemindahan arsip menurut $46,34 \%$ responden berpendapat sering dilakukan, sedangkan menurut $41,46 \%$ responden pemusnahan arsip selalu dilakukan dan pembuatan berita acara dalam pemusnahanarsip selalu dilakukan. Hal ini terjadi karena banyaknya surat yang masuk di Kantor Badan Kepegawaian Negara Regional IV Makassar. Maka dilaksanakannya pemusnahan arsip yang sudah tidak berguna lagi. Pemusnahan arsip berarti menghapus keberadaan arsip dari tempat penyimpanan. Jadi pemusnahan arsip adalah kegiatan menghancurkan secara fisik arsip yang tidak memiliki nilai guna lagi. Dalam pemusnahan tersebut dilakukan dengan total adalah dengan membakar habis sehingga tidak dapat lagi dikenal baik isi maupun bentuknya. Penyerahan dilakukan untuk menghindari penumpukan arsip di lemari dan sudah jadi prosedur dari unit yang bersangkutan untuk melakukan penyerahan tersebut.

\section{Pembahasan}

Pencatatan dan pendistribusian arsip berada pada kategori efektif dengan hasil perolehan $78,24 \%$ berada pada rentang nilai $61 \%$ - $80 \%$. Dengan memperhatikan penerimaan surat masuk yang dikelola dan prosedur penerimaan surat masuk, pendisposisian surat, kemudian proses kembali setelah didisposisi dan pengiriman surat setelah diproses.

Penyimpanan arsip menunjukkan kategori efektif dengan hasil yang diperoleh $80,29 \%$ berada pada rentang nilai $61 \%$ - $80 \%$. Penyimpanan arsip berarti peralatan dan perlengkapan arsip dikantor, merawat arsip, penemuan arsip bila sewaktu-waktu diperlukan tergantung dari tempat penyimpanan, waktu dari pencarian arsip untuk ditemukan kembali. Tempat penyimpanan arsip menggunakan beberapa peralatan seperti lemari khusus tempat penyimpanan arsip. Sedangkan perlengkapan yang digunakan selain lemari adalah map tempat untuk menyimpan dokumen-dokumen lain yang ada di atas meja agar supaya ruang kerja terlihat rapi dan bersih, dan pegawai pun semangat dalam bekerja.

Pemeliharaan arsip menunjukkan kategori sangat efektif dengan hasil yang diperoleh sebesar $82,68 \%$ berada pada rentang nilai $81 \%$ - 100\%. Hal ini dapat dibuktikan dari ruangan yang bersih dan tempat penyimpanan arsip yang tertata rapi sesuai dengan jenis arsip itu sendiri. Pemeliharaan arsip juga dapat berarti memelihara, merawat, menjaga arsip dari kerusakan sehingga arsip dapat bertahan lama dan masih dapat digunakan untuk generasi masa mendatang. Oleh karena itu pemeliharaan dan pengamanan bahan arsip harus dilakukan mengingat kertas sangat rentan terhadap berbagai macam faktor kerusakan.

Penyusutan arsip menunjukkan kategori sangat efektif dengan hasil yang diperoleh sebesar $81,38 \%$ berada pada rentang nilai $81 \%$ - 100\%. Penyusutan arsip 
berarti kegiatan pengurangan arsip atau dasar nilai guna dan retensi arsip dengan memulai pemindahan, pemusnahan maupun penyerahan arsip. Karena arsip tergolong banyak, maka pemusnahan arsip dilakukan oleh pegawai dengan penyaksian dua orang pejabat yang berwewenang dan dibuatkan berita acara pemusnahan, berita acara berarti surat keterangan timbang terima penyerahan arsip sebagai bagian dari prosedur pemindahan arsip. Pemindahan arsip pun dilakukan untuk mengurangi kepadatan filenya, petugas harus dapat memperkirakan arsip mana yang sudah tidak diperlukan lagi.

\section{KESIMPULAN}

Berdasarkan hasil analisis dan pembahasan maka hasil penelitian ini disimpulkan bahwa pengelolaan arsip di Kantor Badan Kepegawaian Negara Regional IV Makassar tergolong sangat efektif, berdasarkan indikator pencatatan dan pendistribusian arsip yang berada pada kategori efektif. Indikator penyimpanan arsip yang berada pada kategori efektif. Indikator pemeliharaan arsip yang berada pada kategori sangat efektif. Dan indikator penyusutan arsip yang berada pada kategori sangat efektif.

\section{DAFTAR PUSTAKA}

Adisasmita, Raharjo. 2011. Pengelolaan Pendapatan dan Anggaran Daerah. Yogyakarta: Graha Ilmu.

Agus Sugiarto. 2015. Management Kearsipan Modern. Yogyakarta: Gava Media.

Ali, Muhammad. 2000. Penelitian Kependidikan Prosedur dan Strategi, Bandung: Angkasa

Amsyah, Zulkifli. 2003. Manajemen Kearsipan. Jakarta: PT Gramedia Pustaka Utama.

Barthos, Basir. 2007. Manajemen Kearsipan untuk Lembaga Negara, Swasta, dan Perguruan Tinggi. Jakarta: Bumi Aksara.

Handayaningrat, Soewarno. 1996. Pengantar Studi Ilmu Administrasi dan Manajemen. Jakarta: HJ Masagung.

Irra Chrisyanti, Dewi. 2011. Manajemen Kearsipan. Jakarta: PT. Prestasi Pustakaraya.

Moekijat. 2000. Fungsi-fungsi Manajemen. Bandung: Mandar Maju.

Peterson, I. (2007). Archival Science. Science News. https://doi.org/10.2307/4016902

Ricciardi, C. (2012). Archives. In Ezra Pound in Context. 
Irwanti, M. Nippi Tambe, Jamaluddin; Efektivitas Pengelolaan Kearsipan.... $\mid 125$

https://doi.org/10.1017/CBO9780511777486.017

Saiman. 2002. Managemen Sekertaris. Jakarta: Ghalia Indonesia.

Schwartz, J. M., \& Cook, T. (2002). Archives, records, and power: The making of modern memory. Archival Science. https://doi.org/10.1007/BF02435628

Siagian, Sondang P. 2001. Manajemen Sumber Daya Manusia. Jakarta: PT Bumi Aksara.

Sudijono, anas. 203. Pengantar satatistika pendidikan. Jakarta: PT. Rajawali pers

Sugiyono. 2013. Metode Penelitian Pendidikan (Pendekatan Kuantitatif, Kualitatif dan $R \& D)$. Bandung: Alfabeta.

Suharsimi, Arikunto. 2002. Prosedur penelitian Suatu Pendekatan Praktek. Jakarta: Rineka Cipta.

Tambe, Nippi. 2008. Manajemen Kearsipan dan Dokumentasi. Makassar: UNM.

Tasyhar, Muhammad. 2013. Kearsipan 1. Cetakan ke-1. Depok: Direktorat Pembinaan Sekolah Menengah Kejuruan. 
126| Jurnal Office, Vol.3, No.2, 2017 